\title{
Anak Luar Nikah Pasca Putusan Mahkamah Konstitusi \\ Nomor: 46/PUU-VIII/2010 Berkaitan Dengan Perlindungan Hukum \\ Terhadap Hak-Hak Keperdataan Anak Di Luar Perkawinan
}

\author{
Farhan Asyhadi ${ }^{1}$ \\ han elza@yahoo.co.id
}

\begin{abstract}
Abstrak
Putusan Mahkamah Konstitusi Nomor 46/PUU-VIII/2010, yang merubah/menambah norma hukum Pasal 43 Ayat (1) Undang-Undang Nomor 1 Tahun 1974 tentang Perkawinan adalah salah satu bukti nyata akan peran lembaga Pengadilan dalam memikirkan nasib dan masa depan anak yang lahir diluar perkawinan itu terhadap laki-laki sebagai ayah biologisnya, maka dengan norma hukum baru itu, Hakim-hakim pengadilan Agama sesuai dengan kewenangannya diharapkan mampu menjabarkan hak-hak keperdataan anak luar nikah dalam putusan-putusannya, agar kedepan hak-hak keperdataan anak seperti itu terhadap laki-laki sebagai ayah biologisnya terjamin sehingga dapat menjalani kehidupannya dengan wajar sebagaimana mestinya tanpa diskriminasi.
\end{abstract}

Kata Kunci: Mahkamah Konstitusi, Perkawinan

Children Married Outside After The Decision Of The Constitutional Court Number: 46 / PUU-VIII / 2010 Relating To Protection Against Civil Rights Child Outside Of Marriage

Constitutional Court Decision No. 46 / PUU-VIII / 2010, which modified / legal norm of Article 43 Paragraph (1) of Law No. 1 of 1974 on Marriage is one of the first concrete evidence of the role of the Court in thinking about the fate and future of children born outside the marriage of a man as the biological father, then the norms of the new law, judges court religion in accordance with the authority is expected to describe the civil rights of children out of wedlock in its

\footnotetext{
${ }^{1}$ Dosen Tetap Program Studi Ilmu Hukum Universitas Buana Perjuangan, han elza@yahoo.co.id, S.E.I (Universitas Islam Negeri Syarif Hidayatullah), M.H.(Universitas Islam Assyafi'iyah)
} 
decisions, that future civil rights to children as against men as the biological father assured so as to live it to the fair as it should without discrimination.

Keywords: The Constitutional Court, Marriage

\section{I . Pendahuluan}

Seiring dengan kemajuan bidang teknologi informasi dan sejalan pula dengan masuknya budaya barat ke Indonesia ditambah semakin merosotnya nilainilai moral keagamaan umat manusia dewasa ini, serta karena dipicu oleh dorongan nafsu seksual yang kuat atas dasar alasan cinta, hubungan seksual manusia dengan lawan jenisnya ada yang dilakukan secara benar yaitu didahului dengan perkawinan yang sah sebagaimana ketentuan agamanya dan ketentuan Undang-undang perkawinan, namun sebagian yang lain ada yang dilakukan melalui cara hubungan seksual diluar ketentuan peraturan perUndang-undangan perkawinan seperti perkawinan sirri, perkawinan dibawah tangan, perkawina kontrak dan lain-lain ${ }^{2}$. Hubungan seksual semacam itu muncul masalah hukum ketika kemudian lahir anak. Masalah hukum tersebut terkait dengan hak-hak keperdataan anak dengan laki-laki sebagai ayah biologisnya, khususnya menyangkut perlindungan hukum atas hak-hak keperdatan anak lahir diluar perkawinan kepada orang tua laki-laki sebagai ayah biologisnya dan keluarga ayah biologisnya, misalnya menyangkut pembuatan akta kelahiran anak, status anak, status hak waris anak, status hak perwalian anak apabila ternyata anak yang lahir perempuan dan sudah waktunya menikah, kemudian hak memperoleh biaya kehidupan, biaya pendidikan dan lain-lain, karena kelahiran anak yang tidak

2 Mustafa Rahman, Anak Luar Nikah Status dan Implikasi Hukumnya, Pustaka, Semarang, 2009. HIm 13.

Jurnal Justisi Ilmu Hukum ISSN 2528-2638 Vol 1, N0 1, September 2016 
didasari oleh perkawinan yang tercatat menurut Undang-undang Perkawinan Nomor 1 Tahun 1974, memunculkan masalah hukum bagi anak keturunannya.

Setitik harapan bagi anak yang lahir demikian (anak lahir diluar perkawinan) muncul, ketika lahir Putusan Mahkamah Konstitusi Nomor 46/PUUVIII/2010, tanggal 13 Pebruari 2012, yang dalam amar putusannya merubah dengan menambah bunyi rumusan Pasal 43 Ayat (1) Undang-undang Nomor 1 Tahun 1974 tentang Perkawinan dimana Pasal yang semula berbunyi "anak yang di lahirkan diluar perkawinan hanya mempunyai hubungan perdata dengan ibunya dan keluarga ibunya" harus dibaca dengan bunyi "anak yang di lahirkan diluar perkawinan hanya mempunyai hubungan perdata dengan ibunya dan keluarga ibunya serta dengan laki-laki sebagai ayahnya yang dapat dibuktikan berdasarkan ilmu pengetahuan dan teknologi dan / atau alat bukti lain menurut hukum mempunyai hubungan darah, termasuk hubungan perdata dengan keluarga ayahnya.$^{3}$

Secara doktrinal hukum, kita sepakat bahwa, apapun bentuknya setiap anak yang lahir di Negara Republik Indonesia haruslah diberikan perlindungan hukum sesuai dengan hak anak itu sendiri terlepas apakah ia anak sah maupun anak luar perkawinan, apalagi perlindungan hukum adalah hak bagi setiap warga Negara Republik Indonesia karena hal itu secara tegas dijamin oleh Konstitusi Negara Kesatuan Republik Indonesia Pasal 27 Ayat (1) Undang-undang Dasar Negara Republik Indonesia 1945 yang berbunyi: Segala warga Negara bersamaan

3 Putusan Mahkamah Konstutusi diakses dari www.badilag.net.pada tanggal 20 Desember 2012. hlm.37. 
kedudukannya didalam hukum dan Pemerintahan dan wajib menjunjung Tinggi hukum dan pemerintahan itu dengan tidak ada kecualinya. ${ }^{4}$

Demikian juga adanya pilihan bangsa Indonesia yang menegaskan dalam konstitusinya bahwa Indonesia sebagai Negara Hukum sebagaimana tercantum dalam Pasal 1 Ayat (3) Undang-undang Dasar Negara Republik Indonesia hasil perubahan yang berbunyi: Negara Indonesia adalah Negara Hukum. ${ }^{5}$ Maka konsekuensi dari adanya pilihan tersebut adalah Negara harus menjadikan hukum sebagai panglima dalam mengawal penyelenggaraan kehidupan berbangsa dan bernegara. Hukum harus diletakkan sebagai pelindung dan perisai bagi setiap warga Negaranya, kepada siapapun tanpa terkecuali termasuk kepada anak meskipun ia lahir dari luar perkawinan seperti akibat perkawinan sirri, perkawinan dibawah tangan dan yang sejenisnya seperti kawin kontrak dan lain-lain, apalagi perlindungan Hukum terhadap anak telah dijamin dalam konstitusi Indonesia sebagaimana tercantum pada Pasal 28 B Ayat (2) Undang-undang Dasar Negara Republik Indonesia 1945 yang berbunyi: Setiap anak berhak atas kelangsungan hidup, tumbuh dan berkembang serta berhak atas perlindungan dari kekerasan dan diskriminasi. ${ }^{6}$ Namun faktanya masalah kemudian muncul ketika anak yang lahir diluar nikah tersebut mengurus hak-hak keperdataannya dilembaga-lembaga pemerintah seperti dicatatan sipil dan lain-lain.

Putusan Mahkamah Konstutusi Nomor 46/PUU-VIII/2010 yang telah dinyatakan berlaku dan mengikat bagi semua warga Negara Indonesia tersebut dalam prakteknya ternyata tidak mampu menjamin sepenuhnya akan hak-hak

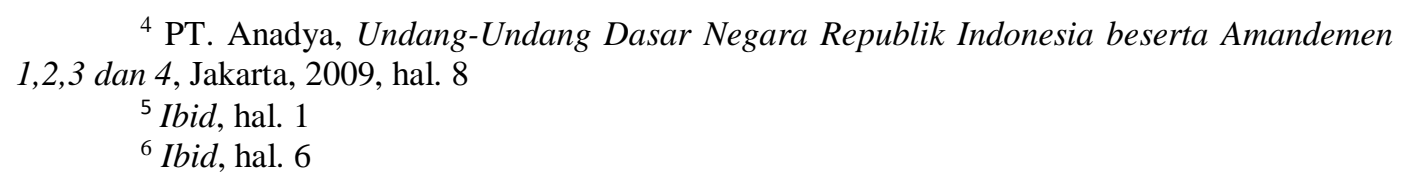

${ }^{4}$ PT. Anadya, Undang-Undang Dasar Negara Republik Indonesia beserta Amandemen 1,2,3 dan 4, Jakarta, 2009, hal. 8

${ }^{5}$ Ibid, hal. 1

${ }^{6}$ Ibid, hal. 6 
keperdataan anak lahir diluar perkawinan. Dalam implementasi pada peradilan tingkat pertama belum semua Hakim menjadikan putusan Mahkamah Konstitusi sebagai dasar pertimbangan hukum dalam memutus perkara pengakuan anak. Hal itu disebabkan masih terjadinya perbedaan pendapat di kalangan teoritis maupun praktisi hukum, munculnya sikap pro dan kontra atas putusan Mahkamah Konstitusi itu tidak hanya sebatas pada tataran keilmuan saja, tetapi sampai pada tataran implementasi di Pengadilan Agama termasuk di kalangan Hakim Pengadilan Agama Blora, sehingga norma hukum perkawinan Pasal 43 Ayat (1) Undang-undang Nomor 1 Tahun 1974 hasil uji materi, dalam tataran implemetasinya mengalami kendala yang serius terutama bagi anak-anak yang lahir diluar perkawinan, sebab tidak semua Hakim-hakim terutama Hakim pada Peradilan Agama Blora menerapkan ketentuan Pasal 43 Ayat (1) hasil uji materi tersebut, satu contoh misalnya dalam beberapa kasus gugatan maupun permohonan pengakuan anak di Pengadilan Agama Blora Nomor 74/Pdt.P/2012/PA.Bla, dan perkara Nomor 1709/pdt.G/2012/PA.Bla, dapat kita temukan Hakim dalam pertimbangan hukumnya tidak menyinggung sama sekali mengenai rumusan Pasal 43 Ayat (1) hasil uji materi tersebut .

Pernyataan tersebut menegaskan bahwa anak dengan segala keterbatasannya tidak berdaya, dan orang dewasalah yang menjadi penentu pada cerah atau suramnya nasib dan masa depan anak. Menurut penulis ada dua alasan penting mengapa anak harus dilindungi, pertama adalah anak sebagai generasi penerus dan masa depan bangsa, ditangan merekalah nasib bangsa ini kedepan dipertaruhkan, Kedua anak adalah kelompok masyarakat yang secara kodrati lemah sehingga harus dilindungi, untuk melindungi anak sebagai asset bangsa, 
maka kebijakan legislasi dan politik hukum Negara yang diwujudkan melalui adanya peraturan perUndang-undangan yang berpihak pada perlindungan dan kepentingan terbaik untuk anak menjadi satu hal yang sangat menetukan, dan dalam pengertian ini tentunya bagi anak-anak yang lahir diluar perkawinan harus pula mendapatkan perlindungan hukum untuk memastikan bahwa kedepan sebagai asset bangsa mereka-mereka itu mempunyai tanggung jawab yang sama sebagai penerus gererasi bangsa.

\subsection{Tujuan Penulisan}

Penulisan ini bertujuan untuk menemukan rumusan mengenai pengertian anak luar perkawinan sebagaimana termaktub dalam putusan Mahkamah Konstitusi Nomor 46/PUU-VIII/2010. mengetahui hak-hak perdata apa saja bagi anak yang lahir diluar perkawinan terhadap laki-laki sebagai ayah biologisnya. untuk mengetahui bagaimana Hakim menjabarkan hak-hak perdata anak luar perkawinan terhadap laki-laki sebagai ayah biologisnya.

\section{ISI JURNAL}

\subsection{Metode Penelitian}

Jenis penelitian yang digunakan adalah penelitiab hukum normative. Penelitian hukum normatif adalah penelitian hukum yang berdasarkan kaidah atau norma dalam peraturan perundang-undangan. Jenis pendekatan yang digunakan adalah pendekatan undang-undang (statute approach). Pendekatan undang-undang ini dilakukan dengan menelaah semua undang-undang dan regulasi yang berkaitan dengan isu hukum yang sedang diteliti.

\subsection{HASIL DAN PEMBAHASAN}

\section{Perlindungan Hukum Terhadap Hak-Hak Keperdataan Anak Luar Kawin}


Munculnya sikap pro dan kontra terhadap lahirnya putusan Mahkamah Konstitusi Nomor 46/PUU-VIII/2010, tanggal 13 Pebruari 2012 dikalangan praktisi hukum maupun teoritisi hukum, adalah berawal dari tidak jelasnya maksud atau pengertian dan batasan anak luar perkawinan dalam Putusan Mahkamah Konstitusi itu sendiri, apakah pengertian anak diluar perkawinan dalam Putusan Mahkamah Konstitusi Nomor 46/PUU-VIII/2010, anak yang lahir dari dan atau akibat perkawinan sirri, perkawinan dibawah tangan atau perkawinan kontrak dan yang sejenisnya atau juga termasuk dalam pengertian itu adalah anak yang lahir dari dan atau akibat hubungan perzinahan ? karena jika yang dimaksudkan dengan anak diluar perkawinan dalam putusan Mahkamah Konstitusi tersebut mencakup didalamnya termasuk anak hasil perzinahan, diyakini bahwa putusan Mahkamah Konstitusi Nomor 46/PUU-VIII/2010 tersebut bertentangan dengan nilai-nilai dan kaidah-kaidah hukum Islam, putusan Mahkamah Konstitusi tersebut dianggapnya sebagai bentuk desakralisasi terhadap nilai-nilai keagungan dan kesakralan sebuah lembaga perkawinan. Bahkan ada yang berpendapat sebagai sebuah komentar hukum bahwa putusan Mahkamah Konstitusi dikatakan sebagai sebuah hasil Ijtihad liar (penemuan hukum yang tidak sejalan dengan prinsip-prinsip hukum Islam). ${ }^{7}$ Karena itu mayoritas para Hakim Pengadilan Agama Blora dalam mengadili perkara pengakuan anak tidak menerapkan Pasal 43 Ayat (1) hasil uji materi Undang-undang Nomor 1 Tahun 1974 tentang perkawinan, meskipun norma hukum tersebut berlaku mengikat bagi semua warga Negara kususnya dalam hal

\footnotetext{
7 DR.H.Habiburrahman, M.Hum “ Anak Luar Nikah dalam Putusan Mahkamah Konstitusi " dalam Varia Peradilan tahun XXVII no. 317 April 2012, Jakarta, hlm.22
} 
perlunya memberikan perlindungan hukum atas hak-hak perdata anak luar perkawinan.

Ketua Mahkamah Konstitusi Mahfudz MD sendiri (waktu itu) sebagaimana dimuat pada koran suara merdeka terbitan kamis tanggal 3 Januari 2013 halaman 3, menyatakan bahwa tidak dilaksanakannya putusan-putusan Mahkamah Konstitusi dalam tataran praktek, karena Mahkamah Konstitusi tidak mempunyai kewenangan "constitusional conplain" sehingga saat ini banyak putusan-putusan Mahkamah Konstitusi yang sudah incrah (berkekuatan hukum tetap) tetapi tidak bisa dijalankan sehingga lembaganya banyak menerima Constitusional conplain dari masyarakat. ${ }^{8}$

Jika kita telaah kembali tentang latar belakang lahirnya Putusan Mahkamah Konstitusi Nomor 46/PUU-VIII/2010, tentang uji materi atas Pasal 2 Ayat (2) dan Pasal 43 Ayat (1) Undang-undang Nomor 1 Tahun 1974 tentang perkawinan terhadap Pasal 28 B Ayat (1) dan (2) Pasal 28 D Undang-undang Dasar 1945. Putusan tersebut keluar adalah dimulai dari adanya permohonan uji materi Aisyah Mohctar dan Muhammad Iqbal Ramadlon bin Drs. Moerdiono yang menganggapnya pemberlakuan ketentuan Pasal 2 Ayat (2) dan Pasal 43 Ayat (1) Undang-undang Nomor 1 Tahun 1974 tentang perkawinan bertentangan dengan Pasal 28 B Ayat (1) dan (2) Pasal 28 D Undang-undang Dasar 1945, sehingga hak-hak konstitusionalnya sebagai warga Negara Republik Indonesia dirugikan dengan pemberlakuan norma hukum Pasal 2 Ayat 2 dan Pasal 43 Ayat (1) Undang-undang Nomor 1 Tahun 1974 tentang Perkawinan.

\footnotetext{
${ }^{8}$ Harian Umum Suara Merdeka, Kamis 3 Januari 2012, Semarang, hlm. 3
} 
Sebagaimana yang didalilkan Aisyah Mohctar bahwa pada tanggal 20 Desember 1993 di Jakarta telah berlangsung pernikahan antara Pemohon Hj. Aisyah Mohtar dengan seorang laki-laki bernama Drs. Moerdiono, dengan wali nikah Almarhum H. Mochtar Ibrahim dengan disaksikan oleh masing-masing almarhum KH. M. Yusuf Usman dan Risman, dengan mahar berupa seperangkat alat sholat,dan uang 2000 riyal (mata uang arab), satu set perhiasan emas berlian dibayar tunai, dengan ijab yang diucapkan oleh wali nikah dan qobul diucapkan oleh laki-laki bernama Drs. Moerdiono.

Lebih jelasnya Drs. Moerdiono adalah seorang laki-laki yang telah mempunyai seorang istri menikah lagi dengan istri yang kedua $\mathrm{Hj}$. Aisyah Mohtar dengan akad nikah secara Islam tetapi tidak dihadapan Pegawai Pencatat Nikah (PPN) Kantor Urusan Agama Kecamatan yang mewilayahi tempat tinggal yang bersangkutan yang berwenang, sehingga perkawinan $\mathrm{Hj}$. Aisyah Mochtar dengan Drs.Moerdiono tidak dicatat dalam buku akta nikah sehingga tidak mempunyai kutipan akta nikah, dan dari perkawinan tersebut dilahirkan seorang anak bernama Muhammad Iqbal Romadlon bin Drs. Moerdiono.

Pasal 2 Ayat (2) Undang-undang Nomor 1 Tahun 1974 tentang Perkawinan menyatakan bahwa tiap-tiap perkawinan dicatat menurut peraturan perundangundangan yang berlaku, kemudian Pasal 43 Ayat (1) menyatakan bahwa anak yang dilahirkan diluar perkawinan hanya mempunyai hubungan perdata dengan ibunya dan keluarga ibunya. Oleh sebab itu baik $\mathrm{Hj}$. Aisyah Mohctar maupun Muhammad Iqbal Romadlon merasa dirugikan hak-hak konstitusionalnya oleh ketentuan Pasal-Pasal tersebut karena perkawinan Hj. Aisyah Mohtar dengan Drs. Moerdiono tidak diakui menurut hukum perkawinan Indonesia (Undang-undang 
Nomor 1 Tahun 1974) dan dengan demikian anak yang dilahirkan dari dan atau akibat perkawinan tersebut yang bernama Muhammad Iqbal Romadlon tidak mempunyai hubungan perdata dengan ayahnya (Moerdiono) dan keluarga ayahnya karena lahir diluar perkawinan yang sah menurut Undang-undang Nomor 1 Tahun 1974 tentang perkawinan.

Putusan Mahkamah Konstitusi Nomor 46/PUU-VIII/2010 yang lahir sebagai jawaban atas gugatan uji materi $\mathrm{Hj}$. Aisyah Mochtar terhadap ketentuan Pasal 2 Ayat (2) dan Pasal 43 Ayat (1) Undang-undang Nomor 1 Tahun 1974 tentang perkawinan terhadap Pasal 28 B dan seterusnya dari Undang-undang Dasar 1945, yang kemudian hanya dikabulkan untuk sebagian atas gugatan uji materi yaitu terhadap Pasal 43 Ayat (1) Undang-undang Nomor 1 Tahun 1974 saja, mengisyaratkan bahwa dalam kacamata Hukum Indonesia sebuah perkawinan mutlak untuk dicatatkan. Sifat pencatatan perkawinan sebagai sebuah peristiwa penting bagi sejarah kehidupan manusia sebagai warga Negara Republik Indonesia, Negara mempunyai wewenang untuk turut campur tangan mengatur guna mewujudkan ketertiban perkawinan dan memberikan perlindungan hukum dan mengatur warga Negaranya demi terciptanya ketertiban hukum perkawinan ditengah-tengah masyarakat, hal ini sejalan dengan ketentuan Pasal 5 Ayat (1 dan 2) Intruksi Presiden Nomor 1 Tahun 1991 tentang pemberlakuan Kompilasi Hukum Islam di Indonesia yang menyatakan bahwa agar terjamin ketertiban perkawinan bagi masyarakat Islam setiap perkawinan harus dicatat, pencatatan perkawinan dilakukan oleh Pegawai Pencatat nikah sebagaimana diatur dalam Undang-undang Nomor 22 Tahun 1946 dan Undang-undang Nomor 32 Tahun 1954, kemudian Pasal 6 Ayat (1) menyatakan untuk memenuhi 
ketentuan Pasal 5 setiap perkawinan harus dilangsungkan dihadapan dan dibawah pengawasan Pegawai Pencatat Nikah, selanjutnya Ayat 2 menyatakan Perkawinan yang dilakukan diluar pengawasan Pegawai Pencatat Nikah tidak mempunyai kekuatan hukum, kemudian Pasal 7 Ayat (1) menyatakan perkawinan hanya dapat dibuktikan dengan akta nikah yang dibuat oleh Pegawai Pencatat Nikah. ${ }^{9}$

Sebagaimana diuraikan diatas, bahwa mengenai perkawinan yang tidak sah dalam kacamata Undang-undang perkawinan di Indonesia adalah perkawinan yang tidak dicatatkan kepada Pegawai pencatat nikah , yakni meliputi perkawinan sirri, perkawinan dibawah tangan dan lain-lain yang sejenis. Jika dilihat dari kasus posisi yang melatar belakangi lahirnya putusan Mahkamah Konstitusi Nomor 46/PUU-VIII/2010, adalah berawal dari kasus perkawinan antara Hj. Aisyah Mochtar dengan Drs. Moerdiono yang tidak dicatatkan karena perkawinan tidak dilakukan dihadapan atau dibawah pengawasan Pegawai Pencatat Nikah, maka dari latar belakang yang demikian jelas bahwa perkawinan $\mathrm{Hj}$. Aisyah Mochtar dengan Drs. Moerdiono adalah "Perkawinan Sirri “.

Perkawinan Hj. Aisyah Mochtar dengan Drs. Moerdiono dikatakan sebagai perkawinan sirri, oleh karena perkawinan tersebut meskipun dilaksanakan dengan memenuhi rukun nikah dalam Islam (sesuai ketentuan Pasal 2 Ayat 1) namun tidak dilaksanakan dihadapan atau dibawah pengawasan pegawai pencatat nikah Kantor Urusan Agama setempat yang mewilayahi tempat tinggalnya, sehingga perkawinan $\mathrm{Hj}$. Aisyah Mochtar dengan Drs. Moerdiono tidak tercatat dan akibatnya tidak memiliki kutipan akta nikah sehingga perkawinannya tidak mempunyai kekuatan hukum.

\footnotetext{
${ }^{9}$ Dirjen.Badilag, Mahkamah Agung RI, Op.cit, hal.319.
} 
Pasal 2 Ayat (2) Undang-undang Nomor 1 Tahun 1974 tentang perkawinan menetapkan bahwa tiap-tiap perkawinan dicatat menurut Undang-undang yang berlaku. ${ }^{10}$ Oleh karena perkawinan sdr. Hj. Aisyah Mochtar dengan Drs. Moerdiono ketika itu tidak dicatatkan, maka perkawinan mereka tidak diakui menurut hukum perkawinan Indonesia dan anak yang lahir dari dan atau akibat perkawinan tersebut dinyatakan sebagai anak luar perkawinan, dan tentunya jika dipahami dari kriteria Pasal 42 dan Pasal 43 Ayat (1) dan (2) Undang-undang Nomor 1 Tahun 1974 tentang Perkawinan, maka anak bernama Muhammad Iqbal Romadlon tersebut masuk dalam kategori anak tidak sah karena anak tersebut lahir diluar perkawinan yang sah menurut Undang-undang perkawinan Indonesia. ${ }^{11}$ Sehingga apabila dikilas balik secara garis besar, maka putusan Mahkamah Konstitusi atas uji materi Pasal 43 Ayat (1) adalah dalam kontek anak yang lahir dari perkawinan sirri yang tidak diakui menurut hukum perkawinan Indonesia, maka pengertian anak di luar perkawinan menurut pemahaman penulis dalam kontek Putusan Mahkamah Konstitusi adalah anak yang lahir dari dan atau akibat perkawinan sirri antara $\mathbf{H j}$. Machica Mohtar dengan Drs. Mordiono bukan anak yang lahir akibat perzinahan seperti pemahaman umum, jika masyarakat umum memahami putusan Mahkamah Konstitusi seperti itu merupakan hal wajar karena kalimat anak luar perkawinan dalam putusan Mahkamah Konstitusi bisa ditafsirkan bermacammacam, anak zina lahir tidak atas dasar perkawinan terlebih dahulu, namun semata-mata karena kumpul kebo, sedangkan anak bernama Mohammad Iqbal Ramadlon bin Drs. Moerdiono adalah anak yang lahir akibat perkawinan yang

\footnotetext{
${ }^{10}$.Dirjend. Badilag Mahkamah Agung RI, Op.cit, hlm. 131.

${ }^{11}$ Drs.Khotib Rasyid,op.cit, Hlm.7
} 
tidak tercatat, dengan demikian jelas bahwa yang dimaksud anak luar perkawinan dalam kontek putusan Mahkamah Konstitusi Nomor 46 /PUU-VIII/2010 adalah anak yang lahir dari dan atau akibat perkawinan sirri, bukan anak hasil perzinahan. Sehingga dari arah pemikiran atau penalaran hukum semacam ini yang termasuk kategori pengertian (term) anak luar perkawinan dalam putusan Mahkamah Konstitusi adalah anak yang lahir dari hasil perkawinan sirri, anak yang lahir dari perkawinan dibawah tangan dan yang sejenisnya. Analisis ini sejalan dengan apa yang dinyatakan Ketua Mahkamah Konstitusi Mahfudz MD saat itu, yang mengklarifikasi pengertian anak luar perkawinan dalam putusan Mahkamah Konstitusi dengan menyatakan: Bahwa yang dimaksud Majelis Hakim Mahkamah Konstitusi dengan Frasa "anak di luar perkawinan“ bukan anak zina, melainkan anak dari hasil perkawinan sirri. Hubungan perdata yang diberikan kepada anak diluar perkawinan tidak bertentangan dengan nasab, waris, dan wali nikah dalam hukum Islam. ${ }^{12}$

Klarifikasi Mahfudz MD, menurut hemat penulis sudah benar, karena putusan Mahkamah Konstitusi Nomor 46/PUU-VIII/2010, tanggal 17 Pebruari 2012, merupakan putusan atas permohonan $\mathrm{Hj}$. Aisyah Mochtar dan Mohammad Iqbal Romadlon bin Drs. Moerdiono, hal mana $\mathrm{Hj}$. Aisyah Mochtar telah menikah secara sirri dengan Drs. Moerdiono, sesuai ketentuan Pasal 2 Ayat (1) Undang-undang Nomor 1 Tahun 1974 tentang perkawinan, oleh karena putusan Mahkamah Konstitusi tersebut mengabulkan permohonan sdr. Hj.Aisyah Mochtar yang sudah menikah dengan Drs. Moerdiono secara sirri, maka sangat naif bila dipahami atau ditafsirkan bahwa pengertian anak luar perkawinan dalam

\footnotetext{
${ }^{12}$ Harian Umum Suara Merdeka terbitan 20 Pebruari 2012, hlm. 1
} 
putusan Mahkamah Konstitusi Nomor 46/PUU-VIII/2010, termasuk didalamnya anak dari hasil perzinahan. Oleh karena itu jika norma hukum Pasal 43 Ayat (1) hasil uji materi diterapkan pada kasus anak luar perkawinan dari hasil perzinahan, menurut hemat penulis maka penerapannya menjadi salah.

Dengan demikian untuk menjabarkan dan menerapkan terhadap umat Islam Indonesia dalam perkara pengakuan anak mengenai "Hubungan perdata anak luar nikah terhadap ayah biologisnya" harus dibedakan sebagai berikut :

a. Untuk anak yang terbukti terlahir sebagai akibat dari pernikahan sirri yang tidak melanggar larangan-larangan menikah sebagaimana ditentukan Undang-undang Nomor 1 Tahun 1974 tentang perkawinan, artinya pernikahannya sah secara Syar'i (Hukum Islam), maka hubungan perdata dapat dimaknai secara umum, sehingga anak luar perkawinan yang seperti ini bisa dinasabkan pada ayah biologisnya, bisa terjadi hubungan saling mewarisi dan tentunya berlaku pula ketentuan wali nikah jika anak terlahir ternyata perempuan, dan tentu saja lakilaki sebagai ayah biologisnya berkewajiban memberikan nafkah secara cukup dan layak untuk kelangsungan kehidupannya .

b. Untuk anak yang terlahir sebagai akibat perkawinan sirri yang tidak sah karena melanggar larangan-larangan dan halangan-halangan menikah yang ditetapkan Undang-undang seperti kasus Hj. Siti Aisyah Muchtar dengan Drs. Murdiono yang melahirkan anak bernama Mohammad Iqbal Romadlon dan anak luar perkawinan yang terlahir dari dan atau akibat perzinahan, maka "hubungan perdata" harus dimaknai secara sempit, artinya kewajiban laki-laki sebagai ayah biologisnya hanya terbatas kepada hak-hak keperdataan yang bersifat umum seperti kewajiban untuk memberikan nafkah secara cukup ,memenuhi segala 
kebutuhan hidup anak sampai anak itu dewasa dan bisa berdiri sendiri, menanggungkan biaya pendidikan anak tersebut dan hak-hak umum lainnya.

\section{KESIMPULAN}

1. Bahwa yang dimaksud anak luar perkawinan dalam putusan Mahkamah Konstitusi Nomor 46/PUU-VIII/2010, tanggal 13 Pebruari 2012, hasil uji materi atas Pasal 43 Ayat (1) Undang-undang Nomor 1 Tahun 1974 tentang perkawinan adalah anak yang lahir dari dan atau akibat dari perkawinan sirri, perkawinan dibawah tangan dan yang sejenisnya, maka anak luar nikah dari hasil hubungan perzinahan tidak termasuk dalam kwalifikasi putusan Mahkamah Konstitusi tersebut.

2. Hak-hak perdata anak luar perkawinan dalam kontek putusan Mahkamah Konstitusi Nomor 46/PUU-VIII/2010, adalah hubungan timbal balik yang mengatur hak dan kewajiban antara seorang anak lahir diluar perkawinan dengan orang lain dalam hal ini ayah biologisnya, meliputi hak-hak perdata yang bersifat umum sebagaimana diatur dalam berbagai peraturan perUndang-undangan maupun peraturan perUndang-undangan yang bersifat khusus seperti Undang-undang Nomor 23 Tahun 2002 tentang perlindungan anak yang secara garis besar meliputi prinsip-prinsip non diskriminasi, kepentingan terbaik bagi anak, hak hidup dan memperoleh kelangsungan hidup dan hak perkembangan serta penghargaan terhadap pendapat anak.

\section{DAFTAR PUSTAKA}

Habiburrahman, DR.H.M.Hum “ Anak Luar Nikah dalam Putusan Mahkamah Konstitusi “dalam Varia Peradilan tahun XXVII no. 317 April 2012, Jakarta.

Harian Umum Suara Merdeka, Kamis 3 Januari 2012, Semarang. 
Anak Luar Nikah Pasca Putusan Mahkamah Konstitusi Nomor: 46/PUU-VIII/2010 Berkaitan

Dengan Perlindungan Hukum Terhadap Hak-Hak Keperdataan Anak Di Luar Perkawinan

Mustafa Rahman, Anak Luar Nikah Status dan Implikasi Hukumnya, Pustaka, Semarang, 2009.

Putusan Mahkamah Konstutusi diakses dari www.badilag.net.pada tanggal 20 Desember 2012.

PT. Anadya, Undang-Undang Dasar Negara Republik Indonesia beserta Amandemen 1,2,3 dan 4, Jakarta, 2009. 